The Sustainable City XIII 419

\title{
INNOVATIVE STRATEGY IN PLANNING FOR THE HISTORIC CITY OF LUOYANG, CHINA
}

\author{
BO BIAN \& DONG WEI \\ School of Architecture, Southeast University, China
}

\begin{abstract}
Nowadays, in China, many cities are developing with new towns constructed in their periphery area. They build traditional style buildings after removing real heritage to preserve its historic cities. While adopting this mode may lead to the deprivation of urban vitality and disintegration of traditional urban form, this paper highlights the south area of Luoyang historic city as an example to find a sustainable renewal method. It first studies the evolution process of historic city and finds the mechanism that the change of city's core function drives the change of urban form and vitality. It shows that historic cities should continue to take up their vital important functions to achieve sustainability. It then introduces the current top-down way of urban renewal in China by comparing different examples of historic cities. It concludes that it is sustainable to consider the urban developing background and integrate its renewal into the overall strategy of urban development by showing the traditional bottom-up method of urban renewal in Luoyang. Next, it introduces a value mechanism (includes space quality, culture quality and social quality) to classify and illustrate the current situation. According to the research, the paper proposes a strategy that the urban renewal work should be based on the basic unit of residential courtyard, which comes from the traditional way of self-construction work that has existed in the past thousands of years in Luoyang. It hopes to acquire a social-economic benefit in conservation and renovation work.

Keywords: historic city, Luoyang, conservation, renovation, heritage, bottom-up.
\end{abstract}

\section{INTRODUCTION}

Currently, urbanization rate of China has reached to 59.58\% [1]. It means that the main body of urban structure has changed from rural area to city. Some cities have experienced old city renewal, while others chose to build new town to protect the old city from demolishment. In the last twenty years, many historic heritage buildings have been destroyed in most cities who chose to renew its old city in China while old cities who were preserved conservatively were also experiencing decline and deprivation of urban vitality, causing disintegration of traditional urban form and activities. How to balance between developing and preserving the old cities turn out to be a difficult question in China [2]. This paper takes the south area of Luoyang historic city as an example to provide sustainable methods for the renewal in old cities.

\section{EVOLUTION OF LUOYANG HISTORIC CITY}

\subsection{Basic information}

Luoyang is one of the four main ancient capital cities in China (Fig. 1(a)). It is the political, economy, and cultural centre in western area in Henan province (Fig. 1(b)). The historical city was built in 1224 A.D. [3]. Although some historical buildings were destroyed during wars, the main structure and pattern of the city were complete. Traditional roads, historical landmarks, old city walls and rivers all survived [4]. Main east-west street and north-south street formed the cross structure of the historical city and divided it in two four main areas [5] (Fig. 1(c)). 


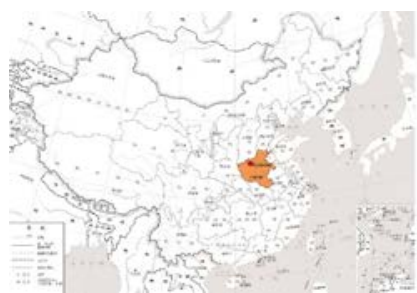

(a)

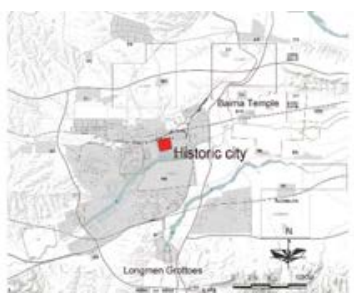

(b)

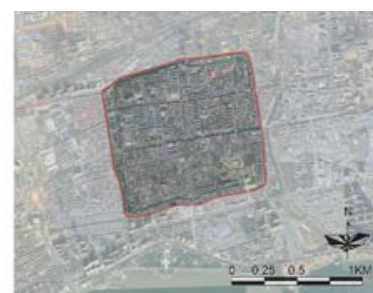

(c)

Figure 1: Location map. (a) Henan province; (b) Luoyang centre district; and (c) Historic city.

\subsection{Time period and space pattern}

The location and proportion of various functional space changed because of the change of regime, city level, transportation and capital market. The evolution process of Luoyang historic city is mainly divided into four parts as listed below.

\subsubsection{Feudal period (1224-1911)}

During this period, the primary task for the emperor was to govern the city and residents. Many agencies include administration, military and warehouse buildings were built in the north area of historic city to show power and authority. While living and commercial space were forced to move to the south area (Fig. 2(a)).

\subsubsection{Republic of China period (1912-1948)}

The extinction of feudal regime and the development of new town outside the historic city resulted in dramatic changes. Authority agencies started to move to the new developing area and the commercial centre moved from the south area to the north area in historic city. While there was more suitable space for public activities in south area (Fig. 2(b)).

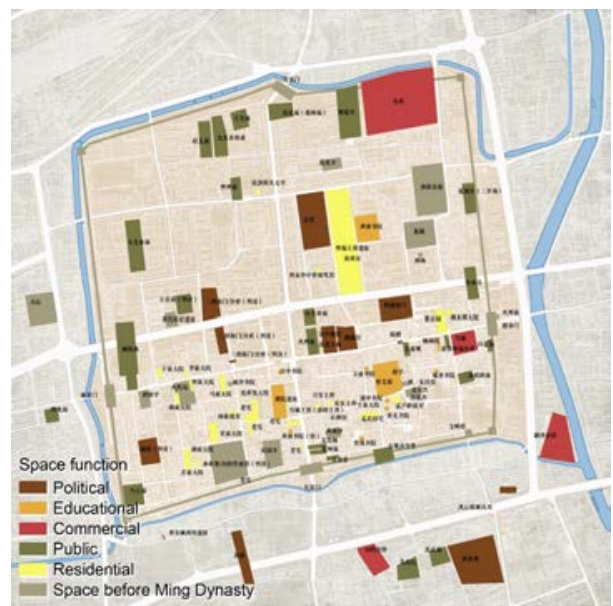

(a)

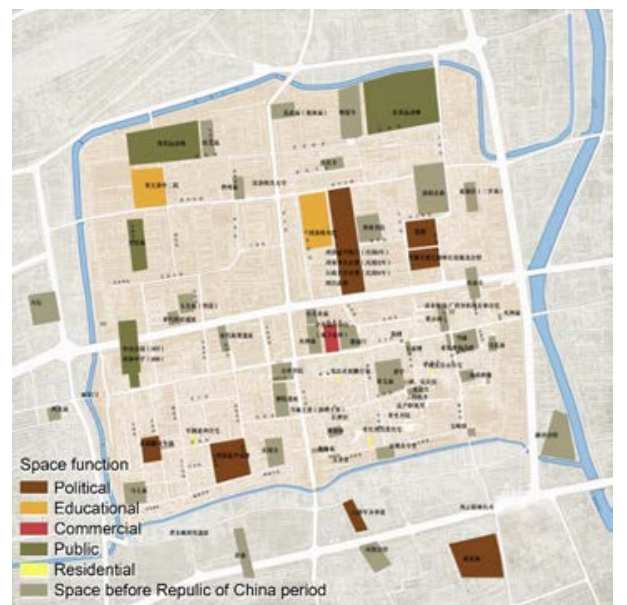

(b)

Figure 2: Location map of function space of different periods. (a) Feudal period; and (b) Republic of China period. 


\subsubsection{The beginning of People's Republic of China (1949-1978)}

The socialist regime changed Luoyang into an industrial city and the historic city started to decline (Fig. 3). Political agencies moved out and residential function occupied the historic city. Although small industrial space took over the space left by agencies, the new town was the focus of the city. Historic city lost its driving force and no longer continuously moved forward. All kinds of space including commercial, residential and public space started to decline.

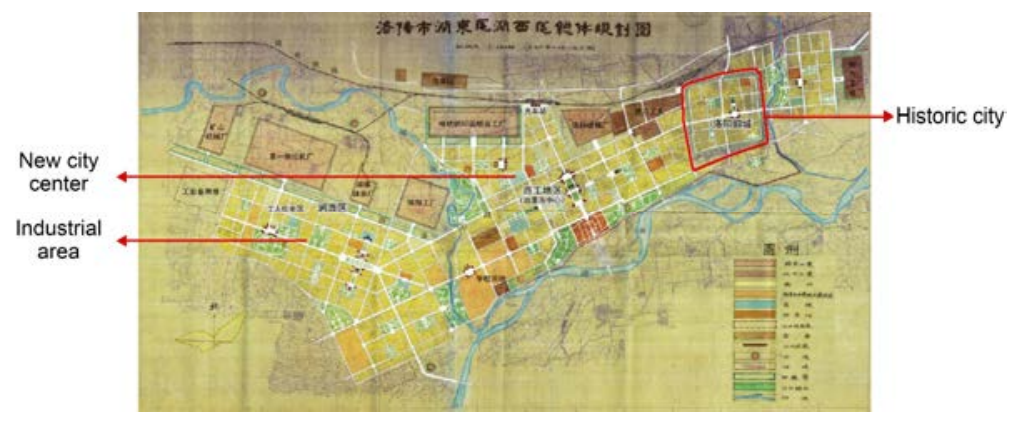

Figure 3: $\quad$ Map of the Luoyang Master Plan 1956. (Source: Bureau of Natural Resources and Planning of Luoyang.)

\subsubsection{Reform and opening period till now (1978-present)}

After the announcing of reform and opening, industry continued to gather in new town under the new market economy condition. Historic city did not receive any supportive policies in many rounds of conservative master plans, accelerating the decline of the historic city. The north area formed large area of modern residential houses after 2000, changing the original urban pattern. On the opposite, the south area retained traditional urban structure, while most houses were in low quality and the living environment was in poor condition.

\subsection{Conclusion}

The core function of the historic city determined the urban vitality. It is necessary to bring new function and integrate it into the city's contemporary and future development.

\section{TRADITIONAL URBAN RENEWAL IN CHINA}

A great number of Chinese cities have started to renew its historic cities, some of them such as Xi'an, Datong and Lijiang have already become typical examples that other cities would follow. Although different cities have their own methods of renewal, their core idea was using the historical resources to rebuild the image and make a brand of the city. They hope that visitors would come to tour around and residents would choose to live here, which would benefit the cities' economy.

In China, one typical way of doing urban renewal project was removing old buildings and rebuilding houses in the style of the ancients (Fig. 4). Another way was driving residents away and renovating the houses in traditional style (Fig. 5). In both methods, antique buildings changed into commercial or residential houses for sightseeing or selling. Residents who used to live in the historic city as well as the function and pattern of the space changed during historic city renewal. Real historical heritage includes both tangible and tangible heritage disappeared because the government seek to acquire short-term benefit. 


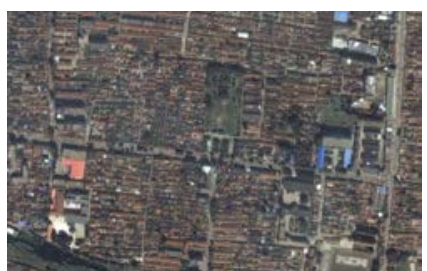

(a)

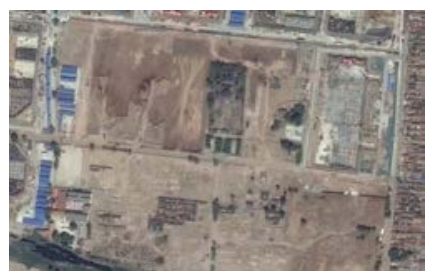

(b)

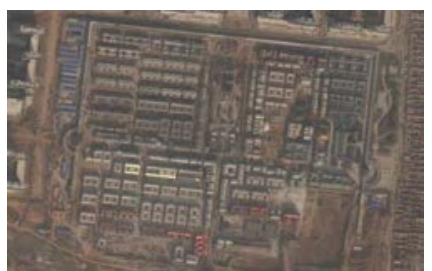

(c)

Figure 4: $\quad$ Maps of the evolution process of Jimo historic city in China. (a) 2012; (b) 2014; and (c) 2016. (Source: Google Maps.)

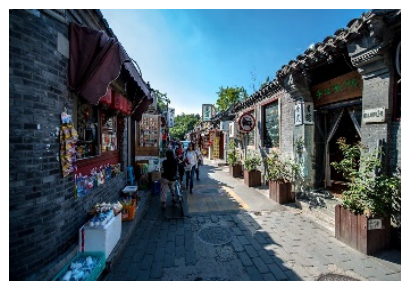

(a)

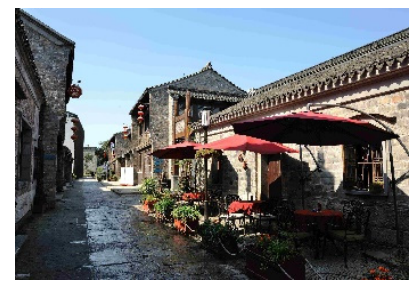

(b)

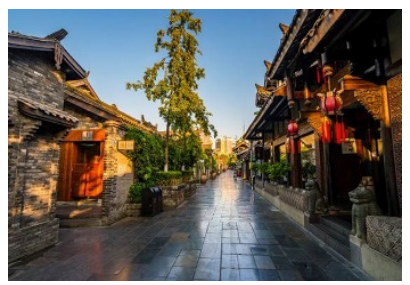

(c)

Figure 5: Similar landscape of the historic city section in different cities. (a) Beijing; (b) Nanjing; and (c) Chengdu. (Source: Baidu Pictures.)

The current way of urban renewal is what we should avoid. However, it is difficult for the government to balance between urban renewal and protecting the real heritage under the conditions of rapid urbanization and high economic demand. Integrating heritage protection into urban renewal is not always an easy task.

\subsection{Two type of urban renewal}

To ensure reliability and locality, it is important to sort out the traditional ways of urban renewal in China before we conduct research. In old days, urban renewal and transformation has always existed in bottom-up ways and it did not have huge influence on city because it happened in partial and sporadic ways. On the opposite, urban renewal usually existed in top-down ways when the dynasty was changing or when the city needed to develop rapidly. Government-led transformation usually had huge impact on the city, lading down the urban structure for the hundreds of years to come.

\subsection{Luoyang historic city renewal in old times}

Traditional Chinese building was usually civil structure architecture and it could be processed localized and flexibly [6]. Thus, every generation has to renovate the house because the building could not exist in good condition for a long time. Small-scale renovation based on family units pushed on bottom-up urban renewal.

This kind of bottom-up renewal was much more obvious in Luoyang historic city. Among the 1800 units of courtyard buildings, only 5\% maintained the original appearance dated back to Ming and Qing Dynasty. The majority were red brick buildings and industrial unit community renovated by residents in recent decades (Fig. 6). 


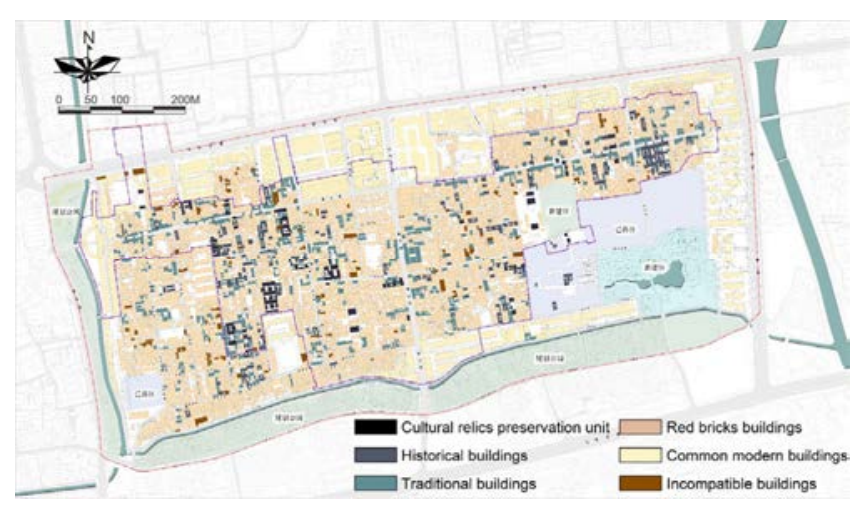

Figure 6: Map of the courtyard buildings' condition.

On one hand, it shows how residents responded to the needs of life in a practical way. On the other hand, it shows that bottom-up renewal was under the permission from government. This whole process illustrates the balance among different social interest groups. Thus, interaction and conflict process formed the valuable culture and it gradually became an institutional habit. This habit was not like the public participation in western world, but it always controlled the development of the historic city in an orderly manner.

\subsection{Conclusion}

Top-down method of urban renewal in contemporary times resulted in dramatic changes in historic cities in China. On one hand, the government tried to make up for the decline of historic city resulted from the loss of maintenance in the past few decades. On the other hand, the government wanted to make profit from removing the old houses and invest in real estate or commercial houses. Consequently, historic city lost its unique culture and history value.

Therefore, government should balance between improving living quality and protecting valuable buildings to ensure the continuity of urban structure of historic city. Moreover, both top-down and bottom-up methods are important during urban renewal in old times so that it is important to manage relationship between different social interest groups.

\section{VALUE EVALUATION}

It is necessary to investigate the specific condition of historic city before we start the planning process. We admit that historic environment is a complex system that includes physical surroundings and intangible environment, built heritage and social culture. Therefore, we come up with a value evaluation that includes space, culture and social quality.

\subsection{Space quality}

The ground of historic city has different layers [7]. It is necessary to study the history of different places and overlie the information on the map of modern city. By doing so, we can explore the quality of different places and promote the continuity of valuable heritage [8].

Although many houses have changed its architectural form, the majority kept its original courtyard units' area. Thus, south area of historic city maintained its original trend of roads, basic land area and city structure. Next, we sort out all the property units and found that residents still owned $82 \%$ of the land. We let residents recognize their own land units, 
encouraging them to rethink about the land. When they are given emotional and financial support, they will intend to improve the environment and take part in urban renewal.

\subsection{Culture quality}

The culture in different periods formed the foundation of contemporary historic city. Although some of the historic sites have been removed, it is practical to display political, commercial or religious culture in modern city based on history information. In addition, plenty of local intangible heritage that have been identified as national intangible heritage are facing the possibility of disappearance result from relocation of residents. It is important to sort out the entire cultural heritage and preserve them by renewing the city.

Preserving and displaying historic culture will benefit the whole city. Residents and visitors are the main population of the historic city. Culture formed by residents is the most important thing that visitors would like to enjoy. The more visitors, the more profit that the historic city will make, and the profit will keep the historic city renewing in a positive way.

\subsection{Social quality}

Top-down mode is the common method of historic city renewal in contemporary China and residents cannot take part in the renewal process as their older generation did over the past hundreds of years. Residents can only receive the demolishing compensation and move out.

It is necessary to collect and assess the social status such as family and income status from both residents and those who have already moved out of the houses and kept it vacant. Then, government and developer can help the residents financially and technically based on the social status. As a result, residents and people who have left their houses could be willing to renew its houses and living environment under suitable policies and financial encouragement.

\section{URBAN RENEWAL PLANNING}

\subsection{Strategy introduction}

According to the analysis above, we propose a strategy (Fig. 7) that the conservation and renovation should be based on the basic unit of residential courtyard, which comes from the traditional way of self-construction work in the past hundreds of years in Luoyang. Renewal does not mean reconstruction of houses in traditional style. It means that the houses in low quality should be renovated based on contemporary technology and then continue to maintain the traditional structure and landscape of the historic city [9]. We encourage the residents to

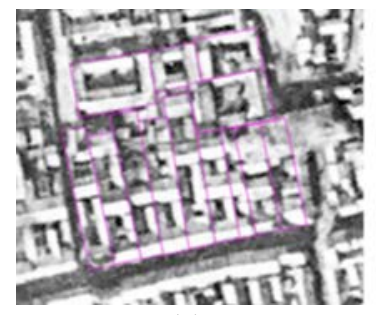

(a)

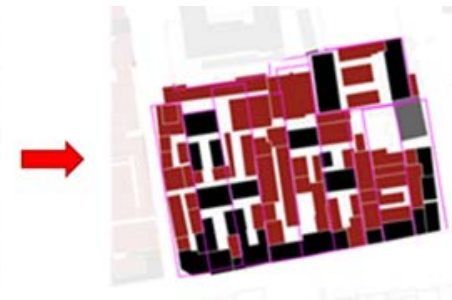

(b)

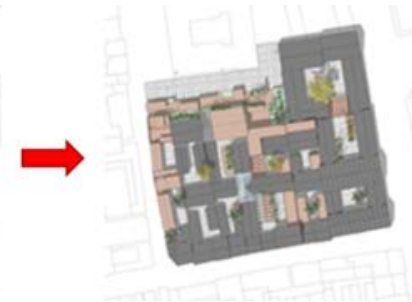

(c)

Figure 7: Schematic maps of the courtyard renewal strategy. (a) Historic structure; (b) Current condition; and (c) Reservation and renovation design. 
continue living in the historic city and inheriting tangible and intangible culture heritage. More importantly, we hope that the residents and the government, as well as developers will form a group of interests to encourage both top-down and bottom-up process, guaranteeing the historic city to develop in a sustainable method. This kind of multi-party coordination is the reason why the historic city could maintain its space structure and culture for so long.

\subsection{Space renewal}

In order to continue the overall structure and style of the historic city, the planning mainly divides the space into three layers that includes street, courtyard and architecture.

To renew streets, planning focuses on the space relationship between different streets, street scale and interface (façade) of the architecture along the streets. The streets fall into three categories based on their history value and current function (Table 1, Fig. 8).

In courtyard renewal processes, planning considers the similarity of the area of property units and courtyard units and divides the courtyards into five categories (Table 2, Fig. 9).

Planning divides buildings into six categories in architecture renewal (Table 3, Fig. 10).

Table 1: Street renewal category.

\begin{tabular}{|l|l|}
\hline Street types & Strategy and intervention \\
\hline Main leading street & $\begin{array}{l}\text { Remove the shanty along the streets. Move the store in the street } \\
\text { into the courtyard. Rebuild the traditional gatehouse and reopen } \\
\text { the channel to strengthen the landscape and historical style. }\end{array}$ \\
\hline $\begin{array}{l}\text { Important traditional } \\
\text { street }\end{array}$ & $\begin{array}{l}\text { Maintain the structure of the street. Classify the buildings along } \\
\text { the street to keep the traditional façade. }\end{array}$ \\
\hline $\begin{array}{l}\text { General traditional } \\
\text { street }\end{array}$ & $\begin{array}{l}\text { Keep the direction of the street. Improve the capacity of streets } \\
\text { appropriately based on fire protection rules. }\end{array}$ \\
\hline
\end{tabular}

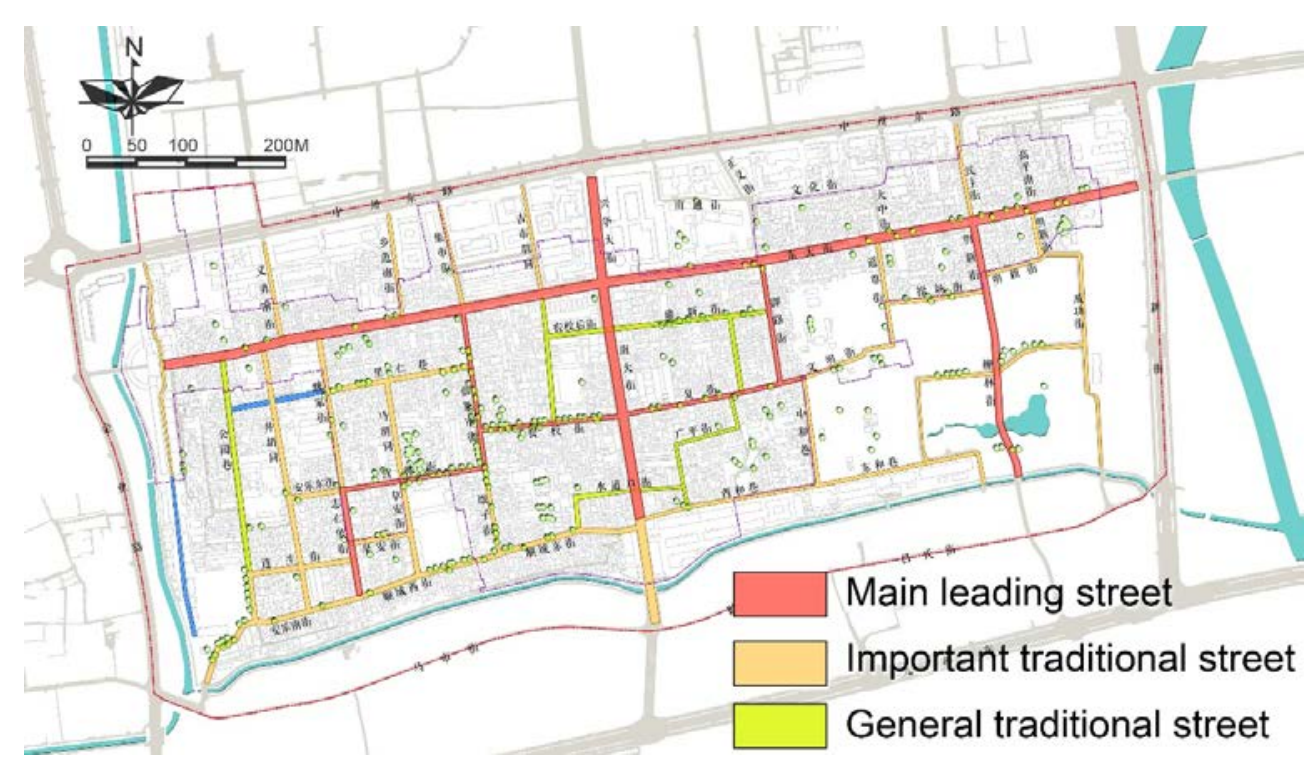

Figure 8: Map of the street renewal category. 
Table 2: Courtyard renewal category.

\begin{tabular}{|l|l|l|}
\hline Intervention & Courtyard types & Specific intervention \\
\hline $\begin{array}{l}\text { General } \\
\text { protection }\end{array}$ & $\begin{array}{l}\text { Well preserved and well- } \\
\text { structured courtyards which } \\
\text { include cultural heritage sites } \\
\text { and historical buildings }\end{array}$ & $\begin{array}{l}\text { Keep the original buildings' } \\
\text { appearance. Buildings' function } \\
\text { should benefit its preservation. Pay } \\
\text { attention to daily maintaining. }\end{array}$ \\
\hline $\begin{array}{l}\text { Promotional } \\
\text { conservation }\end{array}$ & $\begin{array}{l}\text { Common courtyards which } \\
\text { includes cultural heritage sites } \\
\text { or traditional buildings }\end{array}$ & $\begin{array}{l}\text { Maintain buildings' appearance based } \\
\text { on traditional and original form. Do } \\
\text { not demolish buildings. }\end{array}$ \\
\hline $\begin{array}{l}\text { Historical } \\
\text { renovation }\end{array}$ & $\begin{array}{l}\text { Courtyards in traditional } \\
\text { structure or locates in groups } \\
\text { of traditional buildings }\end{array}$ & $\begin{array}{l}\text { Retain modern buildings that are } \\
\text { compatible with traditional buildings } \\
\text { and restore the incompatible part. }\end{array}$ \\
\hline $\begin{array}{l}\text { Structural } \\
\text { renovation }\end{array}$ & $\begin{array}{l}\text { Courtyards which mainly } \\
\text { includes red brick buildings or } \\
\text { few traditional buildings }\end{array}$ & $\begin{array}{l}\text { Transform the buildings and keep } \\
\text { traditional style. Organize courtyards } \\
\text { into functional groups. }\end{array}$ \\
\hline $\begin{array}{l}\text { Chronological } \\
\text { reservation }\end{array}$ & $\begin{array}{l}\text { Modern residential or } \\
\text { commercial buildings }\end{array}$ & $\begin{array}{l}\text { Retain buildings compatible with } \\
\text { traditional style in short term. } \\
\text { Replace incompatible buildings in } \\
\text { long term. }\end{array}$ \\
\hline
\end{tabular}

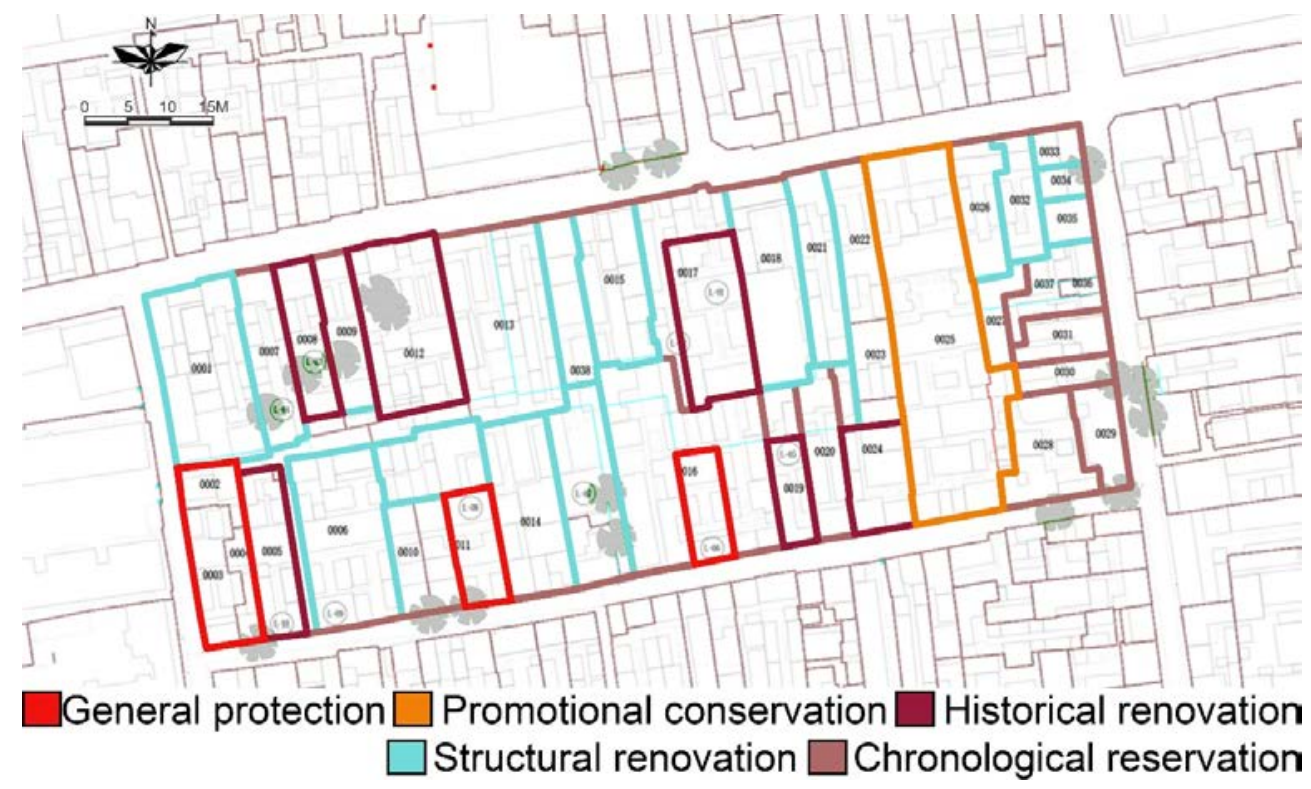

Figure 9: Map of the courtyard renewal category. 
Table 3: Architecture renewal category.

\begin{tabular}{|l|l|l|}
\hline Intervention & Building types & Specific intervention \\
\hline $\begin{array}{l}\text { Maintain original } \\
\text { appearance }\end{array}$ & Cultural heritage sites & $\begin{array}{l}\text { Strengthening maintenance and } \\
\text { repairing }\end{array}$ \\
\hline $\begin{array}{l}\text { Maintain and } \\
\text { improve }\end{array}$ & Historical buildings & $\begin{array}{l}\text { Daily maintenance and } \\
\text { reinforcement }\end{array}$ \\
\hline $\begin{array}{l}\text { Maintain and } \\
\text { renovate }\end{array}$ & $\begin{array}{l}\text { Common traditional } \\
\text { buildings }\end{array}$ & $\begin{array}{l}\text { Restore the appearance in original } \\
\text { style. Do not remove buildings. }\end{array}$ \\
\hline Retain and restore & $\begin{array}{l}\text { Buildings compatible with } \\
\text { traditional style buildings }\end{array}$ & $\begin{array}{l}\text { Renovate the appearance that is } \\
\text { incompatible with traditional style. }\end{array}$ \\
\hline $\begin{array}{l}\text { Restore and } \\
\text { replace }\end{array}$ & $\begin{array}{l}\text { Buildings incompatible with } \\
\text { traditional style buildings }\end{array}$ & $\begin{array}{l}\text { Retain the buildings in short term } \\
\text { and replace it in the long term. }\end{array}$ \\
\hline Remove & $\begin{array}{l}\text { Buildings incompatible with } \\
\text { traditional style in green land }\end{array}$ & $\begin{array}{l}\text { Gradually remove it to recover the } \\
\text { landscape structure of old times. }\end{array}$ \\
\hline
\end{tabular}

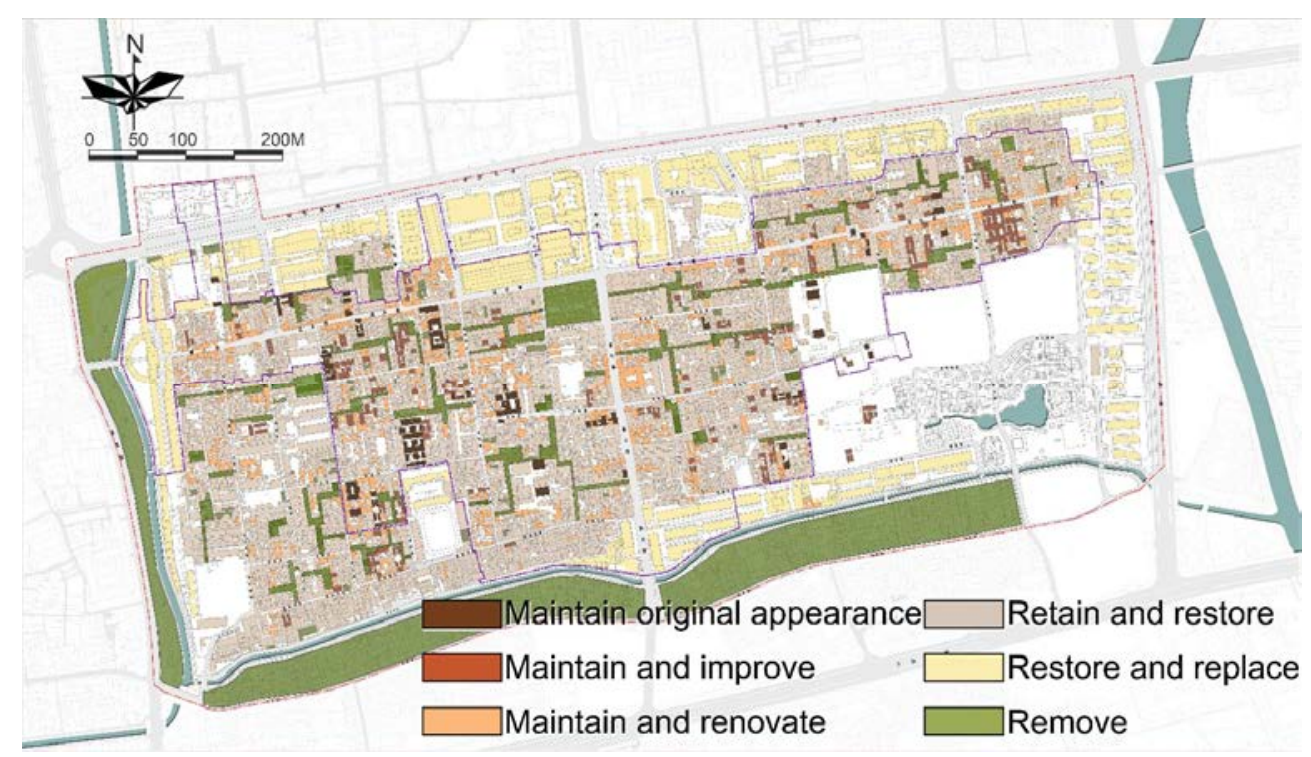

Figure 10: Map of the architecture renewal category.

\subsection{Culture renewal}

The overlapping of land of different dynasties make the abundant historical resources become invisible in modern times. Planners collect the location of various historical sites and valuable culture from doing archaeological survey, reading unpublished ancient books and transferring the information on old maps. Then, the planning restores the historical sites and culture on the map of modern historic city. Based on current structure and pattern of space in the city, the planning forms a history network which includes a variety of exhibition area that displays the entire valuable culture heritage (Fig. 11). 


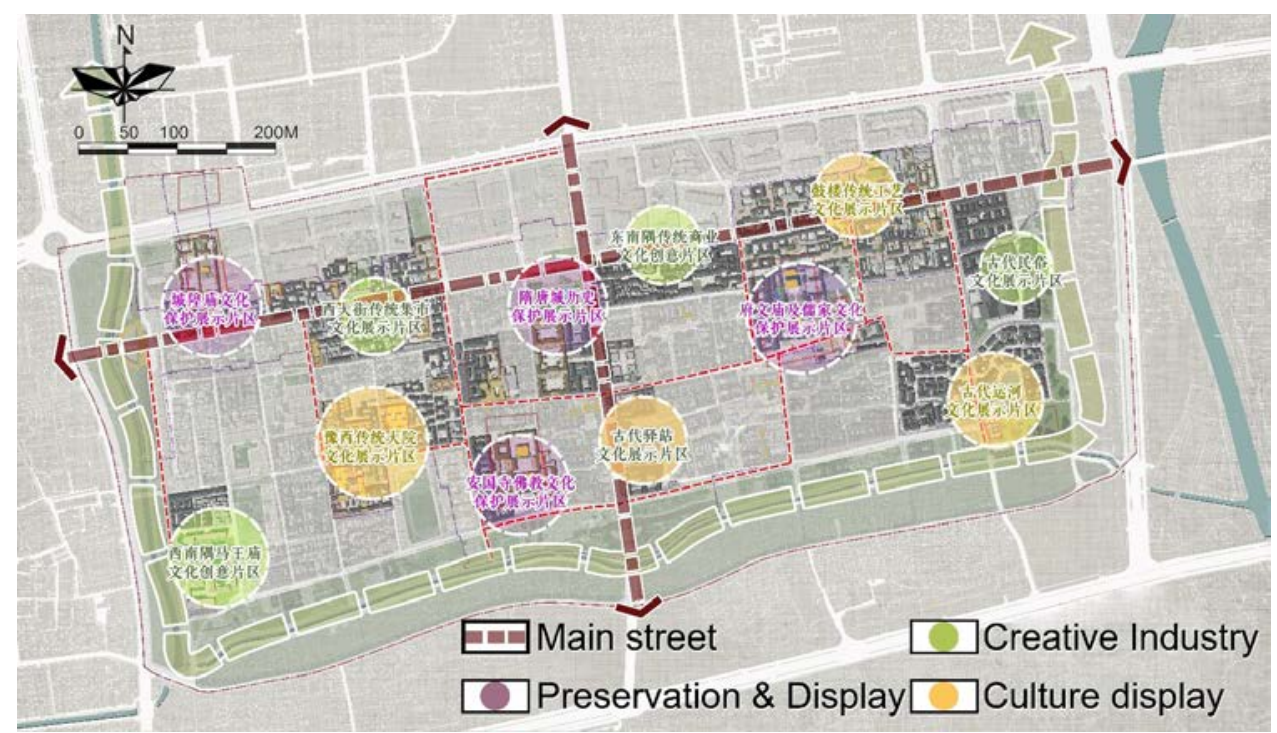

Figure 11: Map of the culture renewal category.

In addition to tangible cultural heritage, the planning combined intangible cultural heritage with commercial courtyards along west east and the south street to better inherit by the residents and show to the visitors.

\subsection{Social renewal}

The primary idea of social renewal in this planning is to improve the status of residents in the groups of different interests to change the imbalance status. Compared to historical buildings, residents are more important in historic city because they are the real inheritor. Planning keep residents as the main body in historic city and encourage those who have already moved out to come back and continue to live here (Fig. 12).

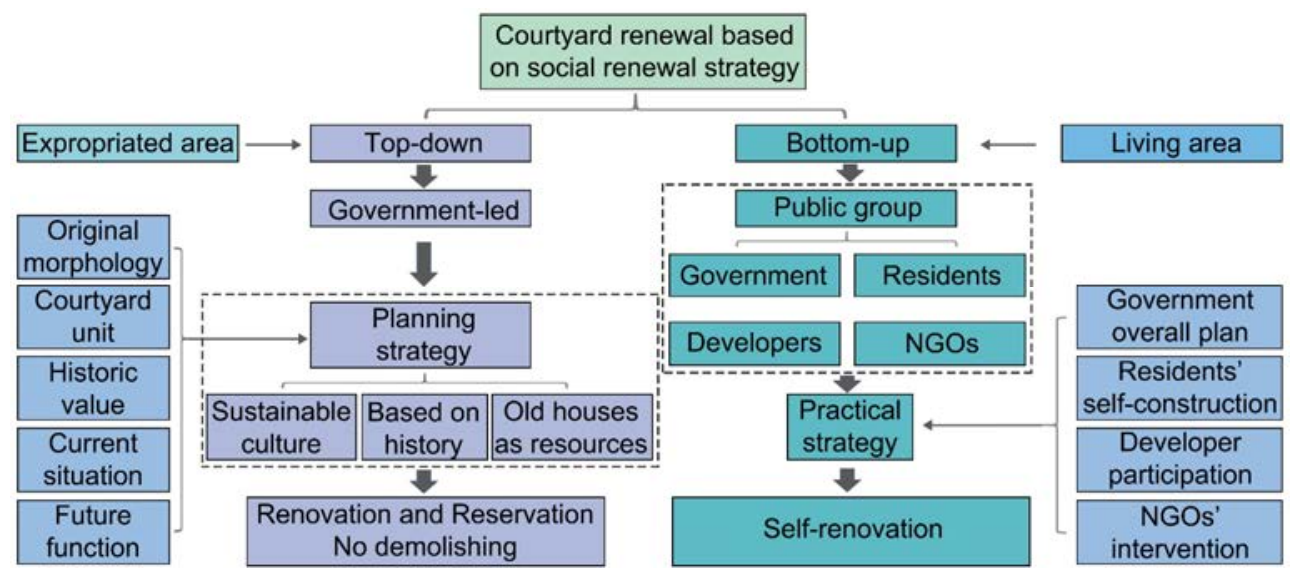

Figure 12: Map of the culture renewal category. 
For the area that has been expropriate by the government, planning advises the government to continue its top-down renewal process. However, it is necessary to avoid development of real estate and commercial in large area, as well as façade renovation that leaves the interior space of buildings in ruined condition. These areas should be renovated based on the courtyard unit and change its function into community infrastructure or displaying the cultural heritage.

For the area where the residents are still living in, residents as well as government and developer can join in to renew it. No matter who will decide the specific design, they all need to follow the restrictions in the planning that are set to control the overall structure and appearance of the historic city.

Next, we give different instructions to people based on their social status as not all the people have adequate ability or are willing to renew their courtyards. The government can give encourage and rewards to those who are willing to renew its courtyards in its family or own tradition. At the same time, for those who are willing to renew its house but are in poor financial condition, the government can give appropriate financial support and renovation instruction based on their social status. We also encourage the residents to coordinate with developers, changing the courtyards into commercial places and share the profit after renewal. Moreover, for those who are willing to move out, government can take over their courtyards and use it for administration or transfer it to the reliable local developers.

Finally yet importantly, the main idea is to improve the status of residents as they held hundreds of years ago. By doing so, we can retain and continue the traditional lifestyle and culture of local residents in modern times. As a result, we can achieve a sustainable mechanism which residents, government and developers can help and benefit each other.

\section{CONCLUSION}

Either building a new town and abandoning the old city or building fake heritage after removing the houses in historic city go against the tradition pattern of urban renewal and ignore the motive force of urban development. It is important to investigate the historic city and seek out the right path through its current situation and history. Urban renewal of the south area of Luoyang historic city emphasize the history network and key elements of the environment. The research studies not only the physical space, but also the culture context and social management. We hope that this systematic planning and design research can provide a sustainable model for similar projects.

\section{ACKNOWLEDGEMENTS}

This paper is based on Luoyang southeast and southwest historic city conservation and renovation plan, Luoyang historical and cultural city planning. These two projects are compiled by Pro. Wei Dong's studio from Southeast University, China.

\section{REFERENCES}

[1] National Bureau of Statistics, Statistical Bulletin on National Economic and Social Development 2018. www.stats.gov.cn/tjsj/zxfb/201902/t20190228_1651265.html.

[2] Wei, D., Ancient Chinese urban wisdom and urban strategy in the environmental era: Inspiration from the stories of The Spring and Autumn of Wu and Yue. Journal of Urban and Regional Planning, 6(1), pp. 66-70, 2013.

[3] The compilation committee of Luoyang old city history, History of Luoyang Old City, Henan People's Press, 1989.

[4] Guoen, L., A town of heaven be chiselled: The conservation planning of Luoyang historic city. City Planning Review, pp. 50-53, 1989. 
[5] Peng, L. \& Wei, D., Study on the evolution of function space in Jin-Yuan Luoyang city and its enlightenment. Modern Urban Research, 27(7), pp. 50-56, 2012.

[6] Zhenmin, G., Ruping, Y. \& Jinyi, Y., A review on "Luoyang approach": Experiences and lessons from the capital construction and cultural heritage conservation. Journal of Huazhong Architecture, 8, pp. 122-126, 2008

[7] Bei, W., Research on the strategy of the archaeological sites protection and urban renewal in the view of 'layering': Take the northern area of Luoyang as an example. $\mathrm{PhD}$ thesis, Zhengzhou University, 2018

[8] Rao, C. \& Wei, D., Study on the conservation of city historic environment based on historical maps: In the case of the old town of Dangtu. Modern Urban Research, 27(7), pp. 50-56, 2012. (In Chinese.)

[9] Yiting, L. \& Wei, Y., Reservation and renovation in historic environment, taking southwest area of Luoyang historic city as an example. Proceedings of Annual National Planning Conference, Urban Planning Society of China, 11(8), 2016. 